Doi 10.5943/ppq/4/2/1

\title{
Fusicladium ahmadii on Pyrus pashia: a new record for Indian mycobiota from Himachal Pradesh
}

\section{Gautam AK}

Department of Botany, Abhilashi Institute of Life Sciences, Mandi-175008 (H.P.) India

Gautam AK 2014 - Fusicladium ahmadii on Pyrus pashia: a new record for Indian mycobiota from Himachal Pradesh. Plant Pathology \& Quarantine 4(2), 86-89, Doi 10.5943/ppq/4/2/1

\begin{abstract}
Fusicladium ahmadii on Pyrus pashia collected from Himachal Pradesh, India is illustrated and described in the present paper with special notes on its morphology and taxonomy. The description of fungus is given along with images of conidiogenous cells and conidia. As per literature consulted, this is the first report of Fusicladium ahmadii from India and probably second from world.
\end{abstract}

Key words - Fusicladium ahmadii -hyphomycetes -Himachal Pradesh -India -new record -Pyrus pashia.

\section{Introduction}

The genus Fusicladium Bonord. (Hyphomycetes) has been frequently studied by various mycologists due to its importance in plant pathology. The fungus is as far as known, anamorph of Venturia Sacc. (Ascomycota, Venturiaceae E. Müll. \& Arx ex M.E. Barr). Fusicladium can be classified into several species based on their distinct morphological characteristics and pathogenicity to number of plant hosts. The different species of the genera includes, Fusicladium asperatum, F. caulicola, $F$. junci, F. nashicola, F. ahmadii, F. byrsonimatis, $F$. catenosporum, $F$. elegans, $F$. mandshuricum, $F$. nebulosum, $F$. oleagineum, $F$. phillyreae, $F$. radiosum var. lethiferum, $F$. radiosum var. populi-albae and Pseudocladosporium caruanianum. About 52 angiospermic plant genera including, members of family fabaceae, fagaceae, juglandaceae, juncaceae, liliaceae and malpighiaceae are reported to infect by this fungi causing characteristic leaf spots, necroses and scab diseases as well as leaf and fruit deformations. These fungi are host specific, mostly confined to a single host genus or allied host genera in a single family (Schubert et al. 2003, Schuller et al. 2003, Michalska \& Polec 2006).

Fusicladium, one genera of hyphomycetes group, have $F$. ahmadii a single species reported to cause infection on Pyrus pashia. The species has been reported first time in Pakistan (Ellis 1976, Schubert et al. 2003), but no other report across the globe. Therefore, the present study was carried out to study morphology and taxonomy of the Fusicladium ahmadii with fresh material on Pyrus pashia collected from Himachal Pradesh, India.

\section{Materials \& Methods}

The infection on leaves of Pyrus pashia L. was noticed during rainy season of two consecutive years i.e. 2008 and 2009. The infected leaves were collected and transported to 
laboratory for further examination of morphology and taxonomy of associated fungal pathogen. The fungus was scrapped from disease spots, placed in a drop of distilled water with lactic acid on a microscope slide and examined under oil immersion by standard light microscopy. An Olympus light microscope was used to examine fungal structures, and a $\mathrm{CH} 2$ Olympus light microscope equipped with a SONY DSC WX200 digital camera was used for photography. Colorless structures of the asexual state were stained with cotton blue for microscopic examination. Fusicladium monograph by Schubert et al. (2003), and other available literature i.e. Beck et al. (2005); Hashemi et al. (2013) was used in fungal identification. A voucher specimen has been deposited at Department of Botany, Abhilashi Institute of Life Sciences, Mandi, Himachal Pradesh, India.

\section{Results}

Pyrus pashia, is a small to medium sized deciduous tree with small and oval shaped leaves, white flowers and small pear-like fruits. The plant is native to southern Asia (Parmar \& Kaushal 1982) and distributed across the Himalayas, from Pakistan to Vietnam and from Southern Province of China to the northern region of India (Krause et al. 2007).

On leaves, diseased spots were observed as mycelial colony, subcircular to irregular, 5-10 $\mathrm{mm}$ in diameter. Colonies amphigenous, punctiform, aggregated in the centre, olivaceous to dark brown. Initially these spots were small, irregular, black, 1-4 mm, which later coalesce into large spots measuring up to $12 \mathrm{~mm}$ (Fig. 1).

\section{Taxonomy}

Fusicladium ahmadii (M.B. Ellis) Ritschel \& U. Braun comb. nov.

Figs. 1 - 3 Synonym - Spilocaea ahmadii M.B. Ellis, More Dematiaceous Hyphomycetes: 114 (1976).

Mycelium olivaceous to dark brown, amphigenous immersed with branched hyphae; hyphae smooth, septate, 1-4 $\mu \mathrm{m}$ wide, and constricted at the septa. Stromata well developed subcuticular in nature, composed of subcircular to slightly angular, pale to medium olivaceous-brown, somewhat thick-walled cells. The size of these cells ranges between 5-10 $\mu \mathrm{m}$ in diameter.

Conidiophores loosely to densely fasciculate, erect, straight to slightly flexuous and unbranched, cylindrical to ampulliform, arising from the upper cells of the stromata, 25-47 $\times 5-6$ $\mu \mathrm{m}, 0-1$ septate, pale to medium olivaceous-brown, smooth, and thick-walled. Conidiogenous cells integrated, terminal, with a single conidiogenous locus, proliferation percurrent, with up to eight conspicuous annellations at the distal end, loci 4-5 $\mu \mathrm{m}$ wide, unthickened, not darkened. Conidia solitary, obclavate, straight to slightly curved, 22.5-35 × 6-9 $\mu \mathrm{m}, 1(-2)$-septate, septum median or somewhat in the lower half, more or less constricted at the septum, pale to medium olivaceousbrown, smooth, walls of the lower cells somewhat thicker than those of the upper one, apex narrowly pointed, base truncate, hila 4-5 $\mu \mathrm{m}$ wide, unthickened, not darkened.

Material investigated - Pyrus pashia L., on both surfaces of leaves, India, Himachal Pradesh, Tanda, Mandi, 760 meters (2,495 ft), 4 November 2013, Ajay Kumar Gautam, (AILS 1007).

Hosts and Distribution - on Pyrus spp. (Rosaceae), Pyrus pashia, Asia (India, Pakistan).

\section{Key for identification of Fusicladium ahmadii:}

1. Conidiogenous cells percurrent .......................................................2

2. Conidia obclavate, 22-35 × 6-9 $\mu \mathrm{m}, 1(-2)$-septate; on Pyrus pashia Fusicladium ahmadii

\section{Discussion}

Fusicladium ahmadii posses close similarities with $F$. pomi, but the percurrent conidiogenous cells and significantly longer and narrower conidia make it different. The occurrence of this fungus on Pysus pashia has only been reported from Pakistan (Schubert et al. 2003) but not detected afterward across the globe. Hence, as per literature consulted, this is the first report of Fusicladium ahmadii from India and probably second from world. 


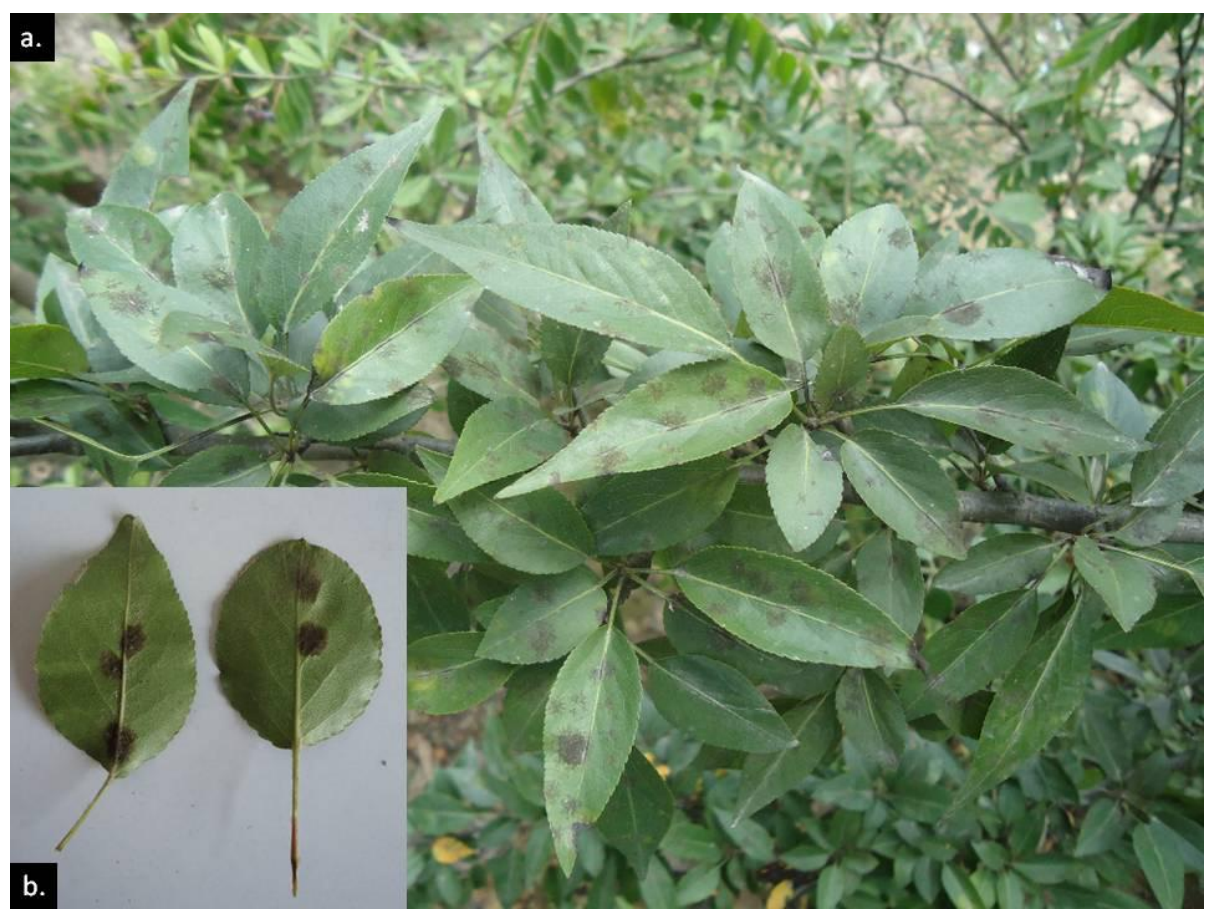

Figs 1 -Leaf showing disease symptoms caused by Fusicladium ahmadii. Fungal colony on leaves: a, Upper side. b, Lower side.

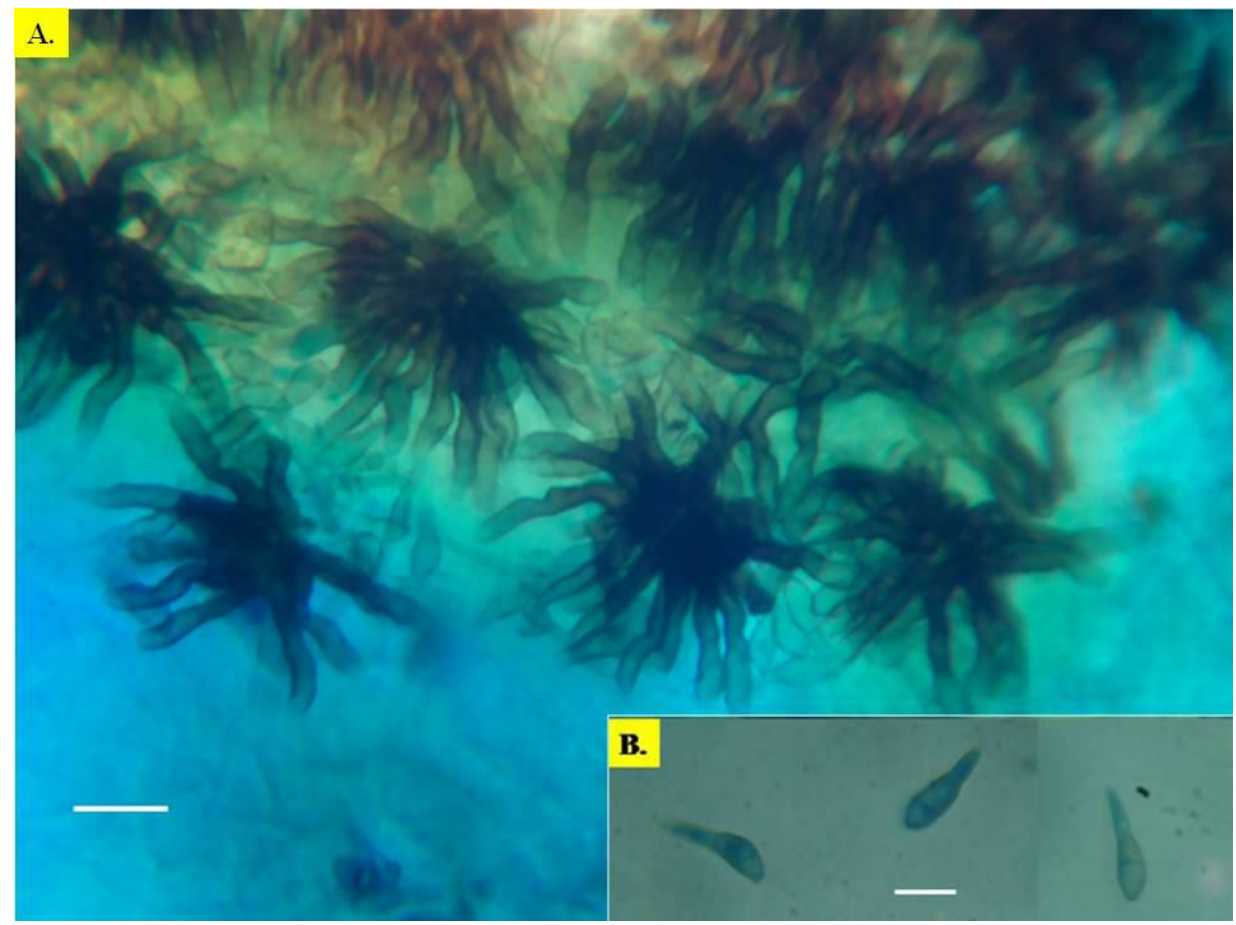

Figs 2 -Conidia and conidiophores of Fusicladium ahmadii. A, Conidiophores with percurrent conidiogenous cells. $\mathrm{B}$, Conidia - bar $=20 \mu \mathrm{m}$. 

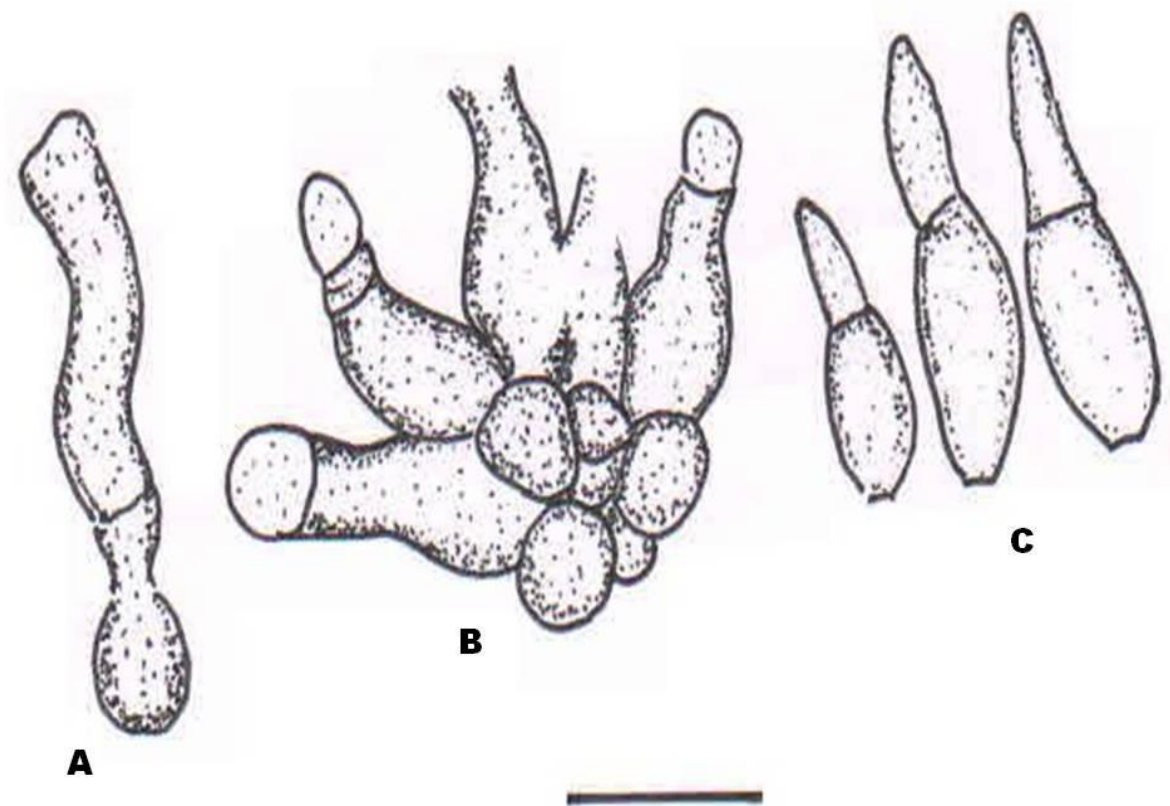

Figs 3 -Fusicladium ahmadii. A, Long septate conidiophore with conidiogenous cell. B, Loose fascicle of conidiogenous cells. C, Conidia. - bar $=20 \mu \mathrm{m}$.

\section{Acknowledgements}

Thanks are due to Head, Department of Botany, Abhilashi Institute of Life Sciences Mandi, Himachal Pradesh, India for providing help in plant identification and Laboratory facilities.

\section{References}

Beck A, Ritschel A, Schubert K, Braun U, Triebel D. 2005 - Phylogenetic relationships of the anamorphic genus Fusicladium s.l. as inferred by ITS nrDNA data. Mycological Progress 4(2), 111-116.

Ellis MB. 1976 - More dematiaceous Hyphomycetes: 114 CMI, Kew.

Hashemi SA, Khodaparast SA, Elahinia SA, Zare R, Mousakhah M. 2013 - A preliminary study on the genus Fusicladium s. 1. in Iran. Mycologia Iranica 1(1), 21-26.

Krause S, Hammer K, Buerkert A. 2007 - Morphological biodiversity and local use of the Himalayan pear (Pyrus pashia) in Central Bhutan. Genetic Resources and Evolution 54(6), 1245-1254.

Michalska MR, Polec E. 2006 - The genus Fusicladium (Hyphomycetes) in Poland. Acta Mycologica 41 (2), 285-298.

Parmar C, Kaushal MK. 1982 - Pyrus pashia Buch. \& Ham, In: Wild Fruits. Kalyani Publishers, New Delhi, India, pp 78-80.

Schubert K, Ritschel A, Braun U. 2003 - A monograph of Fusicladium s.lat. (Hyphomycetes). Schlechtendalia 9, 1-132.

Schuller M, Braun U, Ruhl G. 2003 - Fusicladium levieri, a fungal parasite of persimmon, found in Indiana. Proceedings of Indiana Academy of Sciences 112(2), 132-134. 